\title{
Het Nederlandse IASC-lidmaatschap in de periode 1973-2000
}

\section{Kees Camfferman}

SAMENVATTING Het Nederlands Instituut van Registeraccountants (NIVRA) werd in 1973 uitgenodigd om medeoprichter van het International Accounting Standards Committee (IASC) te worden. Dit getuigt van de sterke internationale positie van het Nederlandse accountantsberoep in die tijd. Het NIVRA heeft zijn zetel in het IASC behouden tot het einde van het bestaan van die organisatie in 2000. Op grond van een historisch overzicht van de tussenliggende periode wordt geconcludeerd dat Nederland weliswaar een respectabele bijdrage aan het IASC heeft geleverd, maar dat toch rond 2000 een verdere rol voor Nederland minder vanzelfsprekend was dan in 1973. Betoogd wordt dat een belangrijke oorzaak hiervan was dat wereldwijd en ook binnen het IASC de aard en de aanpak van regelgeving voor verslaggeving in de besproken periode belangrijk zijn veranderd, maar dat in Nederland deze ontwikkeling onvoldoende is onderkend en nagevolgd.

\section{RELEVANTIE VOOR DE PRAKTIJK International Financial Reporting Standards (IFRS)} worden soms ervaren als vreemde, van buitenaf opgelegde regels. Historisch inzicht in de veranderende Nederlandse betrokkenheid bij het opstellen van deze regels kan helpen bij het onderkennen van de mogelijkheden en beperkingen, om ook vandaag de dag nog vanuit Nederland actief bij de ontwikkeling van IFRS betrokken te blijven.

\section{Inleiding}

Het Nederlands Instituut van Registeraccountants (NIVRA) is vanaf de oprichting van het International Accounting Standards Committee (IASC) in 1973 tot de omzetting van die organisatie in de International Accounting Standards Board (IASB) in 2001 vertegenwoordigd geweest in de board van het IASC. Daarmee behoorde het NIVRA tot de kleine, selecte groep van permanente leden van het IASC. Zeker in een tijd waarin men zoekt naar redenen om weer trots te zijn op Nederland, is het aardig om nog eens terug te kijken op deze voor het NIVRA eervolle episode. Maar omdat er met het einde van het Nederlandse lidmaatschap van het IASC toch ook wel iets verloren lijkt te zijn gegaan, kan inzicht in deze periode ook behulpzaam zijn bij reflectie op de veranderende internationale positie van Nederland op het terrein van de externe verslaggeving. $\mathrm{Na}$ een korte schets van de geschiedenis van het IASC (paragraaf 2) gaat dit artikel in op de volgende vragen: waarom werd het NIVRA eigenlijk gevraagd om toe te treden tot het IASC (paragraaf 3)? Hoe functioneerde de Nederlandse delegatie (paragraaf 4) en welke bijdrage leverde zij aan het vaktechnische werk van het IASC (paragraaf 5)? Wat betekende het Nederlandse lidmaatschap voor de status van het IASC en zijn standaarden in Nederland (paragraaf 6)? Welke houding nam het NIVRA aan ten opzichte van hervormingsvoorstellen, in het bijzonder de vervanging van het IASC door de IASB (paragraaf 7)? En ten slotte: zijn er ook vanuit de antwoorden op deze historische vragen lijnen te trekken naar het heden (paragraaf 8)?

\section{Het IASC in vogelvlucht ${ }^{1}$}

Het IASC werd in juni 1973 opgericht op initiatief van het Institute of Chartered Accountants in England and Wales (ICAEW), in het bijzonder op initiatief van oudvoorzitter Sir Henry Benson. Accountantsorganisaties uit Australië, Canada, (West-)Duitsland, Frankrijk, Ierland, Japan, Mexico, Nederland, het Verenigd Koninkrijk (VK) en de Verenigde Staten (VS) werden uitgenodigd om te overleggen over international accounting standards. De uitgenodigde organisaties besloten tot de oprichting van het IASC, een commissie waarvan zij zelf vooralsnog de enige leden waren. Uit de contributies van de leden werd een aanvankelijk zeer kleine staf gefinancierd, gevestigd in Londen. Verder bestond het IASC vooral uit het committee (later, en ook in het vervolg van dit artikel, 'board' genoemd) dat drie of vier keer per jaar op verschillende plaatsen in de wereld bijeenkwam. In de board hadden alle deelnemende landen één stem (waarbij het VK en Ierland als één land golden), ongeacht het aantal deelnemende organisaties per land (variërend van één voor Nederland, maar ook voor bijvoorbeeld Japan en de VS, tot zes organisaties voor het VK en Ierland). Elk 'land' kon zich in de vergaderingen laten 
vertegenwoordigen door een delegatie van twee personen plus een adviseur.

Het werk van het IASC bestond uit het vervaardigen van 'International Accounting Standards', waarvan de eerste, IAS 1 Disclosure of Accounting Policies in januari 1975 werd gepubliceerd. De standaarden werden voorbereid door per project ingestelde stuurgroepen (steering committees), waarin naast enkele personen uit de board hoofdzakelijk andere door de betrokken organisaties voorgedragen personen zitting hadden.

De board besprak de door de stuurgroepen geproduceerde ontwerpen in een aantal ronden, waarna uiteindelijk met een gekwalificeerde meerderheid besloten werd tot het publiceren van een exposure draft. Op basis van ontvangen commentaren werd vervolgens, opnieuw doorgaans in een aantal ronden, een definitieve standaard vastgesteld, met een grotere gekwalificeerde meerderheid. Met deze procedure bedroeg de doorlooptijd van een project, ook voor de relatief eenvoudige standaarden uit de begintijd van het IASC, al snel drie jaar. Voor een enkel project liep dit op tot tien jaar. Op deze manier werden gedurende de levensduur van het IASC in totaal 41 internationale standaarden uitgegeven, waarvan er sommige later werden vervangen en veel andere één of meer keer zijn herzien.

Geleidelijk aan werd het aantal delegaties in de board uitgebreid tot zestien. Dertien delegaties werden benoemd door nationale accountantsorganisaties (waarbij in sommige gevallen organisaties uit twee of meer landen in één delegatie samenwerkten). Daarnaast waren er uiteindelijk drie delegaties van organisaties van opstellers en gebruikers van jaarrekeningen. Hoewel ook in sommige 'accountantsdelegaties' CFO's, financiële analisten of academici werden benoemd, bleef het IASC in belangrijke mate een organisatie van het internationale accountantsberoep.

Tot het einde van de jaren tachtig van de vorige eeuw werd het IASC in veel landen met welwillende vrijblijvendheid bekeken. Juist in de landen van de oprichters bestond doorgaans de overtuiging dat de eigen nationale verslaggevingsregels zodanig ontwikkeld waren dat het voldoen aan deze nationale regels ook naleving van internationale standaarden impliceerde. Deze beeldvorming was niet altijd terecht, maar wel enigszins begrijpelijk, omdat het IASC tot die tijd betrekkelijk eenvoudige, algemeen geformuleerde standaarden opstelde. In de standaarden werd vaak een keuze geboden uit twee of meer alternatieve waarderings- en resultaatbepalingsgrondslagen. Deze strategie was wellicht goed gekozen in de beginjaren van het IASC, maar bracht het niet-denkbeeldige gevaar met zich mee dat het IASC vooral gezien zou worden als regelgever voor ontwikkelingslanden en dus als irrelevant voor internationale ondernemingen. In 1987 koos het IASC nadrukkelijk voor een andere strategie, waarin juist de ondernemingen met beursnoteringen in verschillende landen centraal stonden. Met de International Organization of Securities Commissions (IOSCO) werd een akkoord bereikt op grond waarvan de leden van IOSCO, dat wil zeggen, de beurstoezichthouders, jaarrekeningen op basis van internationale standaarden zouden accepteren voor internationale noteringen. De voorwaarde was dat het IASC erin zou slagen de standaarden de vereiste eenduidigheid en volledigheid te geven. Gedurende de jaren negentig werden de standaarden daarom ingrijpend herzien. Door de sterke toestroom van buitenlandse ondernemingen naar de Amerikaanse effectenbeurzen kreeg dit project tegen het einde van de jaren negentig het karakter van een spannende race. De vraag was of de herziening van de internationale standaarden op tijd zou kunnen worden afgerond om te voorkomen dat de Amerikaanse Generally Accepted Accounting Principles (US GAAP) de facto de wereldstandaard zouden worden. Hoewel IOSCO zich in 2000 met een aanzienlijk voorbehoud uitsprak ten gunste van de herschreven internationale standaarden, werd deze vraag uiteindelijk niet beslist door IOSCO, maar door de Europese Unie (EU). In hetzelfde jaar 2000 kondigde de EU namelijk aan om de internationale standaarden voor te zullen schrijven voor alle in de EU genoteerde ondernemingen. Op dat moment was echter het einde van het IASC al bepaald. Onder andere als gevolg van Amerikaanse druk was besloten dat erkenning van de internationale standaarden ook vereiste dat de organisatie van de regelgever fundamenteel werd gewijzigd. Het IASC, dat nog steeds 'eigendom' was van het accountantsberoep, werd vervangen door de IASB, een volledig onafhankelijke organisatie. In de nieuwe opzet had geen enkel land of geen enkele organisatie meer recht op één van de veertien zetels in de nieuwe board. Met de laatste board meeting 'oude stijl' in december 2000 eindigde dus ook het Nederlandse lidmaatschap van het IASC.

\section{Nederland en de oprichting van het IASC}

Om te begrijpen waarom het NIVRA werd uitgenodigd om deel te nemen aan de oprichting van het IASC is het nodig om in herinnering te brengen dat het NIVRA (en voór 1967 het NIVA) sinds de Tweede Wereldoorlog een prominente rol speelde in internationale contacten tussen accountantsorganisaties. Een aantal factoren was hierbij van belang. Het NIVA was voor continentaal-Europese begrippen een tamelijk grote accountantsorganisatie, geworteld in een stevige traditie en met een goed geoutilleerd bureau. Het zelfbeeld en de organisatie van het NIVA sloten goed aan bij dat van de Britse accountantsorganisaties, waarmee men reeds lang contact onderhield. Hoewel Limperg niet heeft nagelaten om de verschillen tussen de Nederlandse en de Britse controleaanpak te benadrukken, werd in beide landen erkend dat aan de overkant van de Noordzee het accountantsberoep op een hoog peil stond. Gezamenlijk 
optrekken met de Britse organisaties was dan ook de hoeksteen van een doelbewust buitenlands beleid van het NIVA in de jaren na de Tweede Wereldoorlog. ${ }^{2}$ De succesvolle organisatie van het Internationale Accountantscongres in Amsterdam in 1957 droeg bij aan de naamsbekendheid van het NIVA. Door een consistent beleid om bestuursleden van buitenlandse accountantsorganisaties als gasten uit te nodigen, werden de jaarlijkse Accountantsdagen van het NIVA regelmatig gebruikt voor internationaal 'topoverleg' in de wandelgangen. Als oud-organisator van een Internationaal Congres maakte het NIVRA ook, sinds 1967, deel uit van een kleine maar belangrijke werkgroep die de oprichting van een internationale accountantsorganisatie moest voorbereiden. ${ }^{3}$ Dit betekende dat het NIVRA nauw betrokken was bij de oprichting van de International Federation of Accountants (IFAC) in 1977.

Een andere factor was dat in de jaren zestig van de vorige eeuw de Nederlandse vervangingswaardeleer geleidelijk aan meer bekendheid kreeg in het buitenland. Dit droeg zeker bij aan de reputatie van Nederland als een land waarin serieus en origineel over verslaggeving werd nagedacht.

Met dit alles hadden Nederland en het NIVRA in de jaren zestig en zeventig een sterke internationale reputatie, onder andere blijkend uit een veel geciteerde studie (Mason, 1978). Hierin werd Nederland genoemd als één van de zes vital nations (naast Duitsland, Frankrijk, Japan, het VK en de VS), waarvan de steun onontbeerlijk werd geacht voor een programma van internationale verslaggevingsstandaarden.

Het was voor het NIV(R)A dan ook moeilijk te verteren toen het werd uitgesloten van de in 1966 opgerichte Accountants' International Study Group (AISG). Ook deze groep was een initiatief van de eerder genoemde Henry Benson. Naast het ICAEW namen het American Institute of Certified Public Accountants (AICPA), het Canadian Institute of Chartered Accountants (CICA) en het Institute of Chartered Accountants of Scotland (ICAS) deel. De studiegroep publiceerde tussen 1968 en 1978 een reeks geschriften waarin best practices op het gebied van verslaggeving en accountantscontrole in de deelnemende landen werden vergeleken. Hoewel de groep terughoudend was in het doen van aanbevelingen, worden de publicaties van de AISG toch gezien als een belangrijke eerste stap in de richting van 'international accounting standards'. De eerste voorzitter van het NIVRA, A.F. Tempelaar, heeft herhaaldelijk pogingen ondernomen om voor het NIVRA een plaats in de AISG te veroveren, ${ }^{4}$ maar Benson hield dit af, omdat toelating van Nederland onherroepelijk ook tot toelating van andere landen zou leiden, iets waar de groep naar zijn idee nog niet aan toe was. ${ }^{5}$ Dit bleef een pijnlijk punt voor het NIVRA-bestuur, dat in het najaar van 1972 nog maar eens in zijn beleidsplan opnam dat het wilde 'streven naar het tot stand brengen van een verbinding tussen de [AISG] en de landen van het Europees continent. ${ }^{6}$ Het was dan ook een grote verrassing voor het NIVRA-bestuur dat men deze prijs enkele maanden later al in de schoot geworpen kreeg, in de vorm van een uitnodiging om deel te nemen aan overleg over het op te richten IASC. In het najaar van 1972 hadden de aan de AISG deelnemende landen, opnieuw op initiatief van Benson, besloten dat de tijd rijp was voor het opstellen van internationale standaarden (in tegenstelling tot de meer inventariserende rapporten van de AISG) en dat een beperkt aantal landen zou worden uitgenodigd om dit werk samen met de AISG-leden op te pakken. Dat Nederland uitgenodigd zou worden, lijkt nooit ter discussie te hebben gestaan. ${ }^{8}$ Hoewel het gezien de voorgeschiedenis moeilijk denkbaar zou zijn dat het NIVRA de uitnodiging niet zou aanvaarden, werden binnen het NIVRA-bestuur wel wat kanttekeningen geplaatst. Het nut van internationale standaarden in het algemeen stond daarbij niet ter discussie. Wat wel een rol speelde, was dat het NIVRA Benson al eerder had leren kennen als geduchte behartiger van de Britse belangen,? zodat de strategische implicaties van elk initiatief van zijn kant zorgvuldig gewogen moesten worden. ${ }^{10}$ Een belangrijk aandachtspunt was of het IASC niet ten koste zou gaan van samenwerking binnen Europa. Het NIVRA werkte daar sinds 1963 samen in de Union Européenne des Experts Comptables (UEC) en was via de zogenaamde Groupe d'Etudes betrokken bij het ontwikkelingen van de latere Vierde en Zevende Europese Richtlijn. Het idee dat het IASC vooral een Brits plan was om deze Europese ontwikkelingen te marginaliseren is ook in later jaren nog wel geopperd. ${ }^{11}$ Het NIVRA-bestuur besloot zijn deelname aan het IASC afhankelijk te maken van de beslissing van het Duitse Institut der Wirtschaftsprüfer en de Franse Ordre des Experts Comptables. Omdat deze organisaties al snel lieten blijken tot het IASC te zullen toetreden, waren ook voor het NIVRA eventueel resterende scrupules met betrekking tot Europese solidariteit niet doorslaggevend.

\section{Nederlandse vertegenwoordiging in board en steering committees}

Tabel 1 toont de Nederlandse delegatie in de board, telkens bestaande uit twee personen, die in de meeste jaren vergezeld werden door een staflid van het NIVRA.

Het IASC kende geen regels met betrekking tot de zittingsduur van personen. Deze zittingsduur werd dus bepaald door het beleid van de ledenorganisaties en persoonlijke omstandigheden. Vergeleken met de meeste andere delegaties was de Nederlandse delegatie, zeker vanaf het begin van de jaren tachtig, erg stabiel. Maar ook vóór die tijd gaf het langdurig functioneren van NIVRA-directeur Henk Volten stabiliteit en consistentie aan het Nederlandse optreden in het IASC. Daarnaast liet het NIVRA de delegatie niet aan zijn lot over. Sinds de jaren zeventig werd ervoor 
Tabel 1 De Nederlandse IASC-delegatie

\begin{tabular}{|l|l|l|l|}
\hline Board members & Periode & $\begin{array}{l}\text { Staff observers/ } \\
\text { technical advisers }\end{array}$ & Periode \\
\hline Pieter Louwers (Philips) & $1973-1974$ & Henk Volten (NIVRA) & $1973-1987$ \\
\hline Henk Treffers (Moret \& Limperg) & $1973-1978$ & Cor Regoort (NIVRA) & $1990-1993$ \\
\hline Is Kleerekoper (Klynveld Kraayenhof) & $1975-1979$ & Cees Dubbeld (NIVRA) & $1993-1998$ \\
\hline Hans Burggraaff (Dijker en Doornbos) & $1979-1982$ & Ruud Vergoossen (NIVRA) & $1998-2000$ \\
\hline Jan Uiterlinden (Klynveld Kraayenhof) & $1980-1981$ & & \\
\hline Herman Marseille (Dijker Van Dien) & $1982-1990$ & & \\
\hline Frans Graafstal (Klynveld Kraayenhof) & $1982-1988$ & & \\
\hline Johan van Helleman (Koninklijke/Shell) & $1988-1997$ & & \\
\hline Jan Klaassen (KPMG) & $1991-2000$ & & \\
\hline Jean den Hoed (Akzo Nobel) & $1998-2000$ & & \\
\hline
\end{tabular}

gezorgd dat de delegatie ondersteuning ontving vanuit een begeleidingscommissie, waarmee de agenda van het IASC kon worden doorgesproken.

Net als bij andere delegaties werd Nederland lange tijd vertegenwoordigd door registeraccountants in het openbaar beroep. Toch was hier sprake van een in elk geval symbolisch belangrijke uitzondering. Nederland was het enige land dat al in 1973 een 'verschaffer' in de delegatie opnam in de persoon van Piet Louwers (Philips). Eén van de bezwaren die binnen het NIVRA rond de oprichting van het IASC geuit waren, was dat standaarden die enkel door accountants werden opgesteld onvoldoende draagvlak in het maatschappelijk verkeer zouden hebben. In Nederland was het NIVRA al sinds 1969 in overleg met de werkgeversorganisaties over een inventarisatie van verslaggevingsnormen 'die in het maatschappelijk verkeer als anvaardbaar worden beschouwd'. Sinds 1971, toen ook de vakbonden deelnamen, stond deze activiteit bekend als het Tripartiete Overleg, de voorloper van de huidige Raad voor de Jaarverslaggeving $(\mathrm{RJ}) .^{12}$ In de onderhandelingen over de oprichting van het IASC heeft het NIVRA dan ook de suggestie gedaan dat het IASC de vorm zou aannemen van een soort internationaal Tripartiet Overleg, maar deze gedachte vond geen weerklank bij de andere oprichters. Ook het NIVRA zelf heeft dit punt daarna kennelijk laten rusten, omdat na het terugtreden van Louwers in 1974 geen nieuwe 'verschaffer' werd afgevaardigd. Daardoor werd de Amerikaanse delegatie de eerste die permanent, vanaf 1976, één van de twee plaatsen door een financieel directeur of eem andere ondernemingsvertegenwoordiger liet bezet-ten. Andere delegaties volgden dit voorbeeld pas eind jaren tachtig of begin jaren negentig. Nederland had vanaf 1988 weer een verschaffer in de delegatie. Een factor die hierbij een rol speelde, was dat rond die tijd de belangstelling voor het IASC internationaal begon toe te nemen, waardoor het gemakkelijker werd om vrijwilligers uit het bedrijfsleven te vinden.
Als het gaat om de Nederlandse delegatie verdient Hans Burggraaff bijzondere aandacht. Hij bekleedde, als enige Nederlander, van juli 1980 tot oktober 1982 het voorzitterschap van het IASC. Ook dit dient gezien te worden tegen de achtergrond van de geschetste internationale positie van Nederland. Hoewel het IASC een internationale organisatie was, was in informele zin wel duidelijk dat de oprichting een 'Angelsaksisch' initiatief was. Het was daarom verwonderlijk noch omstreden dat de eerste drie voorzitters uit de Engelstalige wereld kwamen. Toch was duidelijk dat dit niet zo kon blijven voortgaan, te meer niet omdat ook de (kleine) IASC-staf overwegend en tot in de jaren negentig uitsluitend uit de Engelstalige wereld gerekruteerd werd. Het benoemen van een Nederlandse voorzitter was voor de Engelstalige organisaties een makkelijke stap om het IASC wat meer 'uit handen te geven', omdat men het Nederlandse accountantsberoep al langer als min of meer gelijkgezind kende.

Binnen het IASC werd nauwkeurig gelet op de samenstelling van de stuurgroepen, met als gevolg dat Nederland in totaal ongeveer een even groot aantal leden voor deze stuurgroepen heeft geleverd als de meeste andere oprichters. Van de circa zeventig stuurgroepen die in de loop van de tijd werden ingesteld, hadden er 23 een Nederlands lid. Wat het voorzitterschap betreft, was de samenstelling van deze stuurgroepen beduidend minder evenwichtig. De voorzitter was relatief vaak een Amerikaan, Brit of Canadees en iets minder vaak een Australiër of een Fransman. Vergeleken met het record van twaalf Canadese voorzitterschappen steekt het Nederlandse totaal van vier vrij mager af, vooral als men bedenkt dat van de vier er twee betrekking hadden op projecten met een beperkte strekking en één voorzitterschap voortijdig werd afgebroken. ${ }^{13}$ In feite is Jan Klaassen de enige Nederlandse stuurgroepvoorzitter geweest onder wiens leiding een majeur project succesvol werd afgerond. Dit betrof de ingrijpende herziening van de 
pensioenstandaard IAS 19, die tussen 1994 en 1998 zijn beslag kreeg. Jan Klaassen was van 1995 tot 2000 ook lid van het Executive Committee van het IASC waarin de bestuurlijke en beleidsmatige beslissingen van de board werden voorbereid.

\section{Nederlandse bijdrage aan internationale standaarden}

Alle uiteindelijk gepubliceerde internationale standaarden, ook de ogenschijnlijk meest eenvoudige, zijn tot stand gekomen in een proces van schaven en bijstellen dat enkele jaren duurde en waaraan een groot aantal partijen binnen en buiten de board deelnam. In dat licht is het taxeren van de invloed van één bepaalde delegatie een hachelijke zaak. Toch is er wel iets over te zeggen in de zin dat rond sommige onderwerpen in bepaalde landen uitgewerkte ideeën over bepaalde onderwerpen bestonden, waardoor de gang van zaken in de board duidelijk werd beïnvloed. Een markant voorbeeld is IAS 39 over financiële instrumenten, waarvan de uiteindelijke vorm gebaseerd was op een compilatie van de relevante onderdelen van US GAAP, de enige set nationale regels waarin verslaggeving over financiële instrumenten enigszins was uitgewerkt.

De Nederlandse standard setter, het Tripartiete Overleg en later de RJ, had niet als doel om vernieuwende en originele oplossingen voor verslaggevingsvraagstukken te ontwikkelen en was hier ook niet voor toegerust. Het Tripartiete Overleg en de RJ richtten zich in principe op het inventariseren van hetgeen in het maatschappelijk verkeer als aanvaardbaar werd beschouwd. Dit betekende dat de Nederlandse delegatie op basis van de nationale regelgeving doorgaans geen duidelijk onderscheidende bijdrage aan de discussie in de board kon leveren. Daar kwam bij dat de Nederlandse regelgeving door gebrek aan regelmatig geactualiseerde vertalingen ook niet goed toegankelijk was voor de IASC-staf bij het voorbereidende werk ten behoeve van de stuurgroepen.

In de eerste jaren van het bestaan van het IASC was er echter één onderwerp waarop Nederland zich wel nadrukkelijk kon onderscheiden en dat was uiteraard de Nederlandse vervangingswaardeleer. Op dit punt is ook actief getracht een Nederlandse bijdrage te leveren, maar per saldo niet met veel resultaat.

De eerste gelegenheid om dit te doen bood zich aan bij de behandeling van voorraden, een van de onderwerpen op de eerste technische agenda van het IASC. De wat omslachtige titel van IAS 2, Accounting and Presentation of Inventories in the Context of the Historical Cost System (1975) geeft aan dat de Nederlandse delegatie wel geprobeerd heeft om waardering tegen vervangingswaarde in de standaard onder te brengen, maar zich uiteindelijk tevreden moest stellen met de zuinige erkenning van de mogelijkheid van vervangingswaarde in de vorm van een scope exclusion. Toen IAS 2 werd vastgesteld, had het IASC echter ook al besloten om zich bezig te gaan houden met accounting in the face of inflation, een uiterst actueel onderwerp in de jaren zeventig. Dat het NIVRA een plaats kreeg in de stuurgroep voor dit project, was onvermijdelijk en de verwachtingen waren hooggespannen. Het Nederlandse enthousiasme voor vervangingswaarde werd echter internationaal maar zeer beperkt gedeeld. In de Engelstalige landen dacht men eerder in termen van general price level accounting dan in termen van aanpassingen voor specifieke prijsstijgingen. Het gevolg was dat de board geen keuze kon maken en uiteindelijk, in 1977, een zeer zwakke standaard publiceerde. Volgens IAS 6 Accounting Responses to Changing Prices mochten ondernemingen zelf kiezen of zij in de jaarrekening wel of niet met inflatie rekening hielden, en zo ja, of zij dit deden op basis van algemene dan wel specifieke prijsstijgingen. Weliswaar volgde nog een iets stelliger geformuleerde standaard (IAS 15 Information Reflecting the Effects of Changing Prices) in 1981, maar op dat moment was de aandacht voor inflation accounting wereldwijd al over het hoogtepunt heen. Kort daarop zou deze belangstelling volledig wegebben. Hoewel ook IAS 15 wel sporen van Nederlandse inbreng vertoont, is het vermoedelijk altijd een dode letter gebleven. In 1989 verklaarde de board dat voor een volledige toepassing van internationale standaarden het volgen van IAS 15 niet meer verplicht was.

$\mathrm{Na}$ de vervangingswaarde is er nooit meer een onderwerp geweest waarmee vanuit Nederland een duidelijk onderscheidende bijdrage is geleverd. Dit punt wordt ook geillustreerd door het stemgedrag van de delegatie. Tot circa 1980 werden alle exposure drafts en definitieve standaarden door de board met algemene stemmen goedgekeurd. Dat wil niet zeggen dat er geen meningsverschillen bestonden, maar met het oog op het vestigen van de reputatie van de internationale standaarden bestond er een stilzwijgende overeenkomst om deze verschillen naar buiten toe niet te benadrukken. Wanneer dus duidelijk werd dat een standaard de vereiste gekwalificeerde meerderheid zou halen, zetten de overige landen hun resterende bezwaren opzij. Vanaf 1980 werden onthoudingen en tegenstemmen geleidelijk aan gebruikelijker. In de tweede helft van de jaren negentig, met zeer controversiële onderwerpen zoals financiële instrumenten op de agenda, werden verschillende exposure drafts en standaarden slechts met het minimaal vereiste aantal stemmen aangenomen. In de vele eindstemmingen die in de loop der jaren zijn gehouden, heeft de Nederlandse delegatie echter nooit tegengestemd en zich slechts een enkele keer van stemming onthouden. ${ }^{14}$ Dit betekende niet dat de Nederlandse delegatie alles goed vond. De delegatie werd door anderen gezien als actief en capabel. Hoewel binnen het IASC altijd wel kritiek te horen was op afgevaardigden die pas 'in het vliegtuig' hun stukken lazen, werden de Nederlandse afgevaardigden 
doorgaans gerekend tot degenen die hun huiswerk hadden gedaan. Dat gold ook voor het thuisfront: Nederland (anvankelijk het NIVRA zelf, later de RJ) deelt de eer met Zweden (de Föreningen Auktoriserade Revisorer) de meest trouwe correspondent van het IASC te zijn geweest. Vanuit beide landen is op nagenoeg elke exposure draft van het IASC gereageerd. Wat Nederland betreft vertaalde dit huiswerk zich echter vooral in een groot aantal kleine wijzigingsvoorstellen en niet in het innemen van onopgeefbare posities.

De Nederlandse onthoudingen hadden betrekking op de exposure draft en de definitieve versie van IAS 30, Disclosures in the Financial Statements of Banks and Similar Financial Institutions (1990). Deze standaard verbood het vormen van stille reserves, iets wat toen in het Nederlandse bankwezen nog gebruikelijk was in de vorm van de zogenaamde voorziening voor algemene risico's (VAR). De onthouding door de Nederlandse delegatie was een tegemoetkoming aan de Nederlandse banken die hun ongenoegen over deze standaard duidelijk hadden laten blijken. Het was tevens een gebaar met een zuiver symbolisch karakter, omdat noch bij het voorontwerp noch bij de definitieve standaard sprake was van andere tegenstemmen.

Hoewel de Engelstalige landen altijd al de hoofdrol hadden gehad in debatten binnen de board, verschoof het zwaartepunt in de loop van de jaren negentig nog verder in hun richting. De VS, het VK, Canada en Australië konden bij de complexe onderwerpen die in die periode op de agenda stonden, terugvallen op het werk van hun eigen professionele standard setters. Deze regelgevers verenigden zich begin jaren negentig in een studiegroep, die later bekend zou staan als $\mathrm{G}_{4+1}$. Deze groep publiceerde een reeks studies waarin getracht werd innovatieve oplossingen voor verslaggevingsvraagstukken te ontwikkelen. ${ }^{15}$ Hoewel deze regelgevers niet zelf lid waren van het IASC - dat waren de nationale accountantsorganisaties - waren zij vaak wel in de board vertegenwoordigd als delegatielid of technisch adviseur. Binnen de $\mathrm{G}_{4+1}$ bestond consensus over de grote lijnen waarlangs de standaarden zich hadden te ontwikkelen. De belangrijkste kenmerken van deze consensus waren een op beleggers georiënteerde verslaggeving, een balansbenadering en de overtuiging dat de waardering tegen fair value in veel gevallen de voorkeur verdient. Hierdoor had de samenwerking in de $G_{4+1}$, waar men leerde om dit standpunt en zijn consequenties goed te articuleren, het effect dat de prominente rol van de Engelstalige landen in het IASC verder werd versterkt. De Duitse delegatie was eigenlijk de enige die een enigszins coherente alternatieve visie op verslaggeving had, gebaseerd op een rekenschapsrol voor verslaggeving in een vennootschapsrechtelijke context en waarin daarom waardering tegen historische kosten en het voorzichtigheidsbeginsel een belangrijke plaats innamen. De andere delegaties, waar- onder de Nederlandse, leken te aarzelen over de mate waarin zij de visie van de $G_{4+1}$ wilden volgen.

Gezien de traditionele aansluiting van Nederland bij de Engelstalige wereld is het niet verwonderlijk dat de RJ in 1992 informeel gepolst werd om aan de G4 (die toen nog niet als zodanig bekend stond) deel te nemen. Eveneens informeel werd dit door de RJ afgehouden. ${ }^{16}$ Gebrek aan middelen zal hierbij een rol hebben gespeeld: de RJ had immers geen eigen technische staf. Maar het is ook aannemelijk dat in de tripartiete achterban van de RJ de consensus ontbrak over de algemene uitgangspunten van verslaggeving die de samenwerking van de G4-partners kenmerkte. Met andere woorden, ook al is dit in 1992 nooit zo uitgesproken, terugkijkend kan men zich voorstellen dat de RJ er moeite mee gehad zou hebben om zijn naam te verbinden aan sommige van de meer radicale voorstellen die uit de $\mathrm{G}_{4+1}$ voortkwamen, zelfs al hadden zij slechts het karakter van studierapporten.

Het NIVRA heeft nog geprobeerd om een alternatief voor de $\mathrm{G}_{4+1}$ in het leven te roepen in de vorm van de $\mathrm{E}_{5+2}$, een in 1996 opgericht samenwerkingsverband van Europese IASC-leden. ${ }^{17} \mathrm{De} \mathrm{E}_{5}$ is er echter nooit in geslaagd om effectief als groep binnen het IASC te opereren.

\section{Bevordering toepassing IAS in Nederland}

Zoals alle bij het IASC aangesloten organisaties had het NIVRA de verplichting op zich genomen om met aanwending van best endeavours de acceptatie van de internationale standaarden in Nederland te bevorderen. ${ }^{18}$ Wat dit concreet zou betekenen, was bij de oprichting van het IASC uiteraard nog niet zo duidelijk, hoewel de statuten van het IASC erop wezen dat in de accountantsverklaring zou moeten worden vermeld op welke punten een jaarrekening niet aan internationale standaarden voldeed en dat 'geëigende actie' genomen zou moeten worden tegen accountants die zich niet aan deze regel hielden. Al snel bleek echter dat de hoop, of de vrees, dat de internationale standaarden dwingend zouden kunnen worden opgelegd aan ondernemingen, ongegrond was. De meeste bij het IASC aangesloten accountantsorganisaties (met uitzondering van het Canadian Institute of Chartered Accountants) hadden niet zelf de bevoegdheid om verslaggevingsvoorschriften aan ondernemingen op te leggen. Voor de acceptatie van de internationale standaarden was men dus afhankelijk van vrijwillige medewerking van ondernemingen of van de steun van overheden, effectenbeurzen of toezichthouders. Aangezien deze steun in de meeste landen uitbleef en ondernemingen in de regel niet geneigd waren op vrijwillige basis de internationale standaarden te volgen, moest het IASC rond 1980 constateren dat men te maken had met een vrij ernstig nalevingsprobleem.

Tegen deze achtergrond publiceerde het NIVRA-bestuur in 1976 een standpunt over de toepassing van internationale 
standaarden in Nederland. ${ }^{19}$ Het uitgangspunt hierbij was het 'beginsel van volgtijdigheid van de aangegane verbintenissen', waarmee men wilde zeggen dat door het IASC uitgevaardigde standaarden niet zonder meer als bindend werden beschouwd in Nederland. Volgens het bestuur 'kan een Internationale Standaard als hier te lande aanvaard worden beschouwd, wanneer zij in de praktijk frequente toepassing blijkt te vinden of gezaghebbende instanties, zoals Tripartiete Overleg, Vereniging voor de Effectenhandel en de Ondernemingskamer, haar in hun uitingen hebben overgenomen. Het bestuur heeft het voornemen aan de leden mee te delen wanneer een Internationale Standaard in Nederland als algemeen aanvaard moet worden beschouwd. Dit zal van Standaard tot Standaard worden vastgesteld'. Pas na de 'algemeen aanvaard verklaring' zouden accountants verplicht worden, met sancties via het tuchtrecht, om van afwijkingen in de accountantsverklaring melding te maken.

De Vereniging voor de Effectenhandel leek aanvankelijk bereid te zijn om mee te werken. Al in 1974 diende de Vereniging samen met de London Stock Exchange met succes een motie in bij de Fédération Internationale des Bourses de Valeurs (FIBV), waarin de leden van deze federatie werden opgeroepen om naleving van international accounting standards in de noteringsvoorwaarden op te nemen. Voor zover bekend gaven alleen de beurzen van Amsterdam en Londen gehoor aan hun eigen oproep. In Londen was de toepassing van internationale standaarden echter slechts verplicht van 1974 tot 1979. Gedurende deze periode bevatten de internationale standaarden weinig of geen aanvullende eisen ten opzichte van de Britse voorschriften en het lijkt daarom zo te zijn dat de eis weer werd afgeschaft, toen deze meer dan een formaliteit dreigde te worden. In 1978 nam ook de Vereniging voor de Effectenhandel het voldoen aan internationale standaarden op in het fondsenreglement, maar alleen voor zover deze door het NIVRA 'aanvaard' waren. De vereniging speelde daarmee dus de bal weer terug naar het NIVRA.

Maar ook via het Tripartiete Overleg kwam het niet tot een verbindendverklaring van internationale standaarden. Het Tripartiete Overleg was begrijpelijkerwijs niet enthousiast over de mogelijkheid dat de internationale standaarden een eigen leven zouden kunnen gaan leiden in Nederland. Naar aanleiding van de wijziging van het fondsenreglement in 1978 drong het Tripartiete Overleg er bij het NIVRA op aan, dat het NIVRA pas actie zou nemen met betrekking tot een internationale standaard wanneer het Tripartiete Overleg zich hierover had uitgesproken. Het NIVRA-bestuur verklaarde daarop dat het 'de instemming van het Tripartiete Overleg onverminderd gewenst acht alvorens stappen te nemen die een IAS voor genoteerde binnenlandse fondsen verplicht zou stellen'. ${ }^{20}$ Het probleem was echter dat het ook niet lukte om de uitspraken van het Tripartiete Overleg zelf een eenduidig bindend karakter te geven. De omvorming van de 'Beschouwingen' van het Tripartiete Overleg tot 'Richtlijnen' en de oprichting van de Raad voor de Jaarverslaggeving in 1981 ging gepaard met een uitvoerig debat over de status van de Richtlijnen. Dit eindigde er in 1984 mee dat de RJ, vooral op aandringen van de werkgeversdelegatie, voor zijn Richtlijnen alleen een 'intrinsiek gezag' claimde. De RJ zag daarmee af van een formele verplichting om afwijkingen van de Richtlijnen in de jaarrekening of de accountantsverklaring te vermelden. Ook binnen het NIVRA werd getwijfeld of men wel over de bevoegdheid beschikte om door een 'algemeen aanvaard verklaring' gezag aan de Richtlijnen te verlenen. In die situatie was het niet te verwachten dat het Tripartiete Overleg of de RJ wèl bereid zou zijn om medewerking te verlenen aan een verbindendverklaring van internationale standaarden. Binnen het NIVRA werd in 1980 dan ook al geopperd dat het bestuur in 1976 'te ver' was gegaan met het plan om internationale standaarden 'algemeen aanvaard' te verklaren. ${ }^{21}$ Hoewel de verklaring van 1976 voor zover bekend nooit is ingetrokken, heeft het NIVRA nooit rechtstreeks een internationale standaard algemeen aanvaard verklaard. In plaats daarvan besloot het NIVRA om zijn verplichtingen jegens het IASC geheel via de RJ na te komen. In het jaarverslag van de RJ werd in de jaren tachtig altijd de zin opgenomen: 'Het NIVRA . . . heeft ter zake van de toepassing van de IASC-Standaarden medegedeeld dat een Standaard als algemeen aanvaard moet worden beschouwd indien hij door de RJ in de Richtlijnen is verwerkt.' Daarmee verdwenen de internationale standaarden als zelfstandige norm voor de Nederlandse verslaggeving in feite geheel uit beeld. Bij de herziening van het Fondsenreglement in 1983 werd de verwijzing naar internationale standaarden geruisloos verwijderd. ${ }^{22}$ Het volgende jaar meldde het NIVRA dat het niet langer Nederlandse vertalingen zou maken van IASC exposure drafts en IASC-standaarden en dat men in het vervolg deze teksten ook niet langer, zoals tot dan toe steeds gedaan was, integraal af zou drukken in De Accountant. Als reden werd gegeven een 'verminderde belangstelling [die zich weerspiegelt in] het sterk teruggelopen aantal reacties van individuele leden, kantoren en diensten dat op de internationale discussie-ontwerpen wordt ontvangen'. ${ }^{23}$ Dat binnen het NIVRA geen hooggespannen verwachtingen bestonden over de toekomstige activiteiten van het IASC, blijkt wellicht uit de opmerking dat het IASC de belangrijkste onderwerpen behandeld had en zich vooral bezig zou gaan houden met herziening van de eerder uitgevaardigde standaarden.

Invoering van de internationale standaarden via de RJ was wellicht de enige reële mogelijkheid die het NIVRA in de jaren tachtig had, maar het had wel tot gevolg dat het internationale geluid vertraagd en gedempt in Nederland doorklonk. Zo hield de RJ bijvoorbeeld vast aan enkele 
algemeen geformuleerde aanbevelingen met betrekking tot gesegmenteerde informatieverstrekking, lang nadat IAS 14 (1981) vroeg om segmentatie van omzet, bedrijfsresultaat en activa naar bedrijfstak en geografische gebieden. In 1989 stond de RJ nogal kritisch tegenover het streven van het IASC om, in het kader van de nieuwe strategie, het aantal opties in de internationale standaarden terug te dringen. ${ }^{24}$ Wellicht mede dankzij de toenemende internationale reputatie van het IASC werd echter vanaf circa 1990 geleidelijk aan een wat andere houding bij de RJ zichtbaar. Waar de nadruk eerst leek te liggen op het verwerken van IAS in de Richtlijnen 'voorzover aanvaardbaar', werd het beleid vanaf 1991 verwoord als: 'Het streven van de RJ is, dat de Richtlijnen waar mogelijk in overeenstemming zijn met de internationaal aanvaarde grondslagen'. ${ }^{25}$ De vertaling van het Conceptual Framework van het IASC, dat in 1992 als 'Stramien' in de RJ-bundel werd opgenomen, past in ditzelfde beeld. Vanaf 1997, naar aanleiding van de overeenkomst tussen IOSCO en het IASC, richtte de RJ zich nadrukkelijker dan ooit op het zoveel mogelijk verwerken van internationale standaarden in de Richtlijnen. ${ }^{26}$ Eigenlijk was men daar toen echter al te laat mee. In die tijd waren de internationale standaarden zo in beweging en veranderden zij ook zodanig van karakter, dat zich allerhande spanningen begonnen voor te doen tussen de internationale standaarden en het wettelijk kader van Titel 9 Boek 2 BW. Deze problemen deden zich overigens niet alleen in Nederland voor. In de hele Europese Unie werden de laatste jaren van de twintigste eeuw gekenmerkt door grote onzekerheid over de verdere ontwikkeling van het institutionele kader van de verslaggeving en over de rol van nationale regelgeving in het licht van de toenemende betekenis van de internationale standaarden en US GAAP. Ook in Nederland werd serieus gesproken over mogelijkheden als het toestaan van rechtstreekse toepassing van internationale standaarden of US GAAP door Nederlandse ondernemingen. ${ }^{27} \mathrm{Net}$ als in andere lidstaten van de Europese Unie werd ook in Nederland aan deze onzekerheid een einde gemaakt door het in 2000 bekendgemaakte voornemen om de standaarden van het IASC voor beursgenoteerde ondernemingen in de EU voor te schrijven met ingang van 2005. Daarmee, en door het min of meer gelijktijdige besluit tot de opheffing van het IASC, verdween in formele zin het probleem van de agenda van het NIVRA hoe men zijn verantwoordelijkheid met betrekking tot de bevordering van het gebruik van internationale standaarden moest nakomen.

De gehele periode overziend moet geconstateerd worden dat het NIVRA slechts beperkt succes heeft gehad in de bevordering van de toepassing van internationale standaarden in Nederland. Gedurende de levensduur van het IASC is het slechts zeer sporadisch voorgekomen dat ondernemingen in hun jaarrekening melding maakten van toepassing van internationale standaarden. Het beleid van invoering van internationale standaarden via de RJ betekent uiteraard dat de feitelijke invloed van internationale standaarden groter zal zijn geweest dan uit dergelijke expliciete vermeldingen blijkt. Maar dit beleid had twee zwakke punten. In de eerste plaats heeft de RJ, aanvankelijk bewust en later ook door gebrek aan middelen, de ontwikkeling van de internationale standaarden niet volledig gevolgd. In de tweede plaats werden de RJ-richtlijnen niet altijd volledig nageleefd. Rond 2000 was het cumulatieve effect van deze verschillen zo opgelopen dat de integrale invoering van internationale standaarden voor beursgenoteerde ondernemingen kon worden voorgesteld als belangrijke maatregel om de kwaliteit van de Nederlandse verslaggeving te verhogen (Hoogendoorn en Mertens, 2000, p. 45). ${ }^{28}$ Hierin werd Nederland ingehaald door landen als Zwitserland en Duitsland waar volledige toepassing van internationale standaarden, op basis van vrijwilligheid, aan het einde van de jaren negentig meer gebruikelijk begon te worden.

\section{Reorganisatie en uiteindelijke opheffing van het IASC}

Zoals aangegeven had het NIVRA al bij de oprichting van het IASC aandacht gevraagd voor de noodzaak om het 'maatschappelijk verkeer', of op zijn minst een bredere groep dan alleen de oprichters, te betrekken bij de ontwikkeling van internationale standaarden. Deze gedachte vond toen nog weinig weerklank, maar kreeg een tweede kans in het begin van de jaren tachtig. In die tijd werd duidelijk dat nog maar weinig voortgang was geboekt op het gebied van acceptatie en naleving van internationale standaarden. Bovendien stond het IASC bloot aan toenemende kritiek. Deze kritiek kwam enerzijds van de vele accountantsorganisaties die buiten de besloten kring van de oprichters waren gebleven en daarom als associate members van elke feitelijke zeggenschap waren uitgesloten. Deze groep pleitte voor incorporatie van het IASC in de in 1977 opgerichte International Federation of Accountants (IFAC). Als IFAC-commissie zouden de leden van het IASC door IFAC voor vaste termijnen benoemd worden, zodat de geprivilegieerde status van de oprichters zou verdwijnen.

Tegelijkertijd stond het IASC ook onder kritiek vanuit de Verenigde Naties (VN) en de Organisatie voor Economische Samenwerking en Ontwikkeling (OESO). Binnen deze organisaties ontstond belangstelling, met een politiek getint karakter, voor de verslaggeving van multinationale ondernemingen en werd gezocht naar manieren om hiervoor regels of normen uit te vaardigen. Het IASC liet uiteraard niet na om zich als de geëigende instantie hiervoor op te werpen, maar was voor velen binnen OESO en VN niet acceptabel als gesloten, privaatrechtelijke orga- 
nisatie waarin - en dat was vooral voor de VN bezwaarlijk - geen enkel ontwikkelingsland enige zeggenschap had. Het is met name IASC-voorzitter Burggraaff geweest die de reactie van het IASC op deze soms tegenstrijdige kritiek heeft geformuleerd. Zowel Burggraaff als de Nederlandse delegatie waren van mening dat het IASC behoefte had aan grotere legitimiteit, zowel door meer accountantsorganisaties als ook andere maatschappelijke geledingen bij het werk van het IASC te betrekken. Dat laatste betekende ook dat het voor hen niet acceptabel was om het IASC te laten 'overnemen' door IFAC, omdat dit juist het eenzijdige accountantskarakter van het IASC zou versterken. Het uiteindelijk onder Burggraaffs leiding gevonden compromis was dat het IASC als afzonderlijke organisatie naast IFAC zou blijven bestaan, maar dat IFAC de leden van de board (dat wil zeggen: de organisaties) voor bepaalde termijnen zou benoemen. Hoewel hiermee in principe de bijzondere status van de oprichters verdween, werd deze feitelijk gehandhaafd, doordat IFAC zich verplichtte om een ruime meerderheid in de board te benoemen uit 'the most significant countries in terms of the status and development of the accounting profession or that are of significant importance to international commerce and trade'. Met de eerste categorie werd vooral gedoeld op het VK en de VS, met de tweede categorie op Duitsland en Japan. Hoewel in die tijd het Nederlandse accountantsberoep, zoals eerder aangegeven, hoog stond aangeschreven, is aannemelijk dat men zich er binnen het NIVRA van bewust was dat het niet vanzelfsprekend was dat Nederland tot in lengte van dagen deel zou blijven uitmaken van de IASC-board. Het NIVRA had dan ook tijdens de onderhandelingen als enige oprichter duidelijk uitgesproken dat men in principe bereid was zijn zetel op te geven met het oog op de benodigde legitimiteit van het IASC. In de praktijk is er echter, voor zover bekend, tot het eind van het IASC nooit sprake van geweest dat het NIVRA niet als board member zou worden herbenoemd.

Tegelijk met deze wijzigingen maakte Burggraaff zich sterk voor de oprichting van een 'Consultative Group'waarvan vertegenwoordigers van ondernemingen, vakbonden, financiële analisten en andere betrokkenen deel zouden uitmaken om het IASC over het werkprogramma en andere vragen te adviseren. Deze groep kwam in 1981 voor het eerst bijeen. Hoewel ook het Nederlandse Tripartiete Overleg als inspiratiebron bij de opzet van deze groep zal hebben gegolden, moet bedacht worden dat ook andere standard setters, zoals de Amerikaanse Financial Accounting Standards Board (FASB), al vergelijkbare adviesgroepen hadden. Een verdere stap werd genomen door het toevoegen van een delegatie van financiële analisten aan de board in 1986, in 1995 en 1996 gevolgd door twee delegaties van 'verschaffers'. Deze toevoegingen vonden plaats binnen het raamwerk dat in 1982 was vastgesteld.

$\mathrm{Na}$ de spanningen van rond het jaar 1980, werd de opzet van het IASC voor het eerst weer fundamenteel ter discussie gesteld in de tweede helft van de jaren negentig door het samenlopen van twee ontwikkelingen. De eerste was het streven naar acceptatie van de internationale standaarden door IOSCO. Dit riep de vraag op of sommige partijen, met name de SEC, niet als voorwaarde voor deze acceptatie zouden stellen dat het IASC meer onafhankelijk moest worden gemaakt van het accountantsberoep, maar ook van de nu in de board vertegenwoordigde ondernemingen. De tweede ontwikkeling was de profilering van de Engelstalige regelgevers in de $\mathrm{G}_{4+1}$, waaruit potentieel een alternatief voor het IASC kon ontstaan. De samenloop van deze ontwikkelingen school vooral in het feit dat de SEC en de G4-regelgevers in grote lijnen dezelfde visie hadden op de gewenste verdere ontwikkeling van de regelgeving. Hierdoor kwam het IASC onder aanzienlijke druk te staan om zich te reorganiseren en de nationale regelgevers - lees: de $\mathrm{G}_{4}$ - meer invloed te geven ten koste van de accountantsorganisaties. Vanzelfsprekend werd dit niet zonder meer aanvaard door IASC-leden die geen $\mathrm{G}_{4}$-standard setter hadden en door de inmiddels, als waarnemer, nauw bij het IASC betrokken Europese Commissie. Tussen 1996 en 1999 werd hierover taai onderhandeld. Begrijpelijk genoeg was er in Nederland, net als in veel andere landen, weinig steun voor voorstellen om de $\mathrm{G}_{4}$ de facto een overwegende stem in een nieuwe opzet te geven. Het NIVRA en de andere in de RJ samenwerkende partijen gaven de voorkeur aan een opzet waarin een rol was weggelegd voor een bredere kring van standard setters - vermoedelijk bedoeld: met inbegrip van de RJ - en waarin de uiteindelijke zeggenschap lag bij een board met een globaal op de RJ lijkende structuur en waarvan de samenstelling in belangrijke mate door IFAC bepaald zou worden. ${ }^{29}$ Kennelijk hoopte of wenste men een structuur waarin voor Nederland, al was het op rotatiebasis, een plek was weggelegd. In de laatste fase van de onderhandelingen bleek echter dat de Amerikaanse SEC alleen een volledig onafhankelijke board wilde accepteren, opgezet volgens de lijnen van de FASB. En hoewel tot op het laatst onderhandeld werd over de mogelijkheid van regionale zetels (bijvoorbeeld een aantal zetels te bezetten door de Europese Unie) moet al snel duidelijk geweest zijn dat Nederland, in tegenstelling tot bijvoorbeeld het VK, Frankrijk of Duitsland, geen reële kans had om een dergelijke regionale zetel structureel te bezetten. In de eindfase van de onderhandelingen heeft de Nederlandse delegatie zich, voor zover bekend, in het op dat moment onvermijdelijke geschikt. Net als de andere delegaties in de board van het IASC heeft men voór de wijzigingen gestemd, op grond van de overweging dat zonder overeenkomst het IASC ook geen toekomst zou hebben. ${ }^{30}$ 


\section{Nabeschouwing}

In het licht van de vanzelfsprekendheid waarmee Nederland bij de oprichting van het IASC werd uitgenodigd om tot dit selecte gezelschap toe te treden is het een voor de hand liggende vraag of Nederland de verwachtingen heeft waargemaakt. Wanneer we het voorgaande overzien, lijkt de conclusie gerechtvaardigd dat het IASC met Nederland in elk geval niet beschaamd is uitgekomen. Het NIVRA heeft achtereenvolgens capabele mensen naar het IASC gestuurd, waarvan sommigen groot respect verwierven. De Nederlandse delegatie werd goed ondersteund en heeft met inzet en een constructieve instelling geparticipeerd. Men was, wellicht meer dan sommige andere delegaties, bereid om eigen belangen en standpunten opzij te zetten voor het belang van het geheel. Van dit laatste getuigt niet alleen het nagenoeg ontbreken van Nederlandse tegenstemmen in de eindstemmingen over standaarden, maar ook het vroegtijdig signaleren dat ook niet-accountants bij het werk van het IASC betrokken zouden moeten worden en de getoonde bereidheid om de eigen, aanvankelijk permanente zetel op te geven als dat nodig zou zijn om het IASC meer draagvlak te bezorgen.

Met dit alles is Nederland zonder meer een gewaardeerd lid van het IASC geweest. Dat dit echter iets anders is dan een vital nation, kan wellicht worden afgeleid uit de ontwikkelingen sinds de oprichting van de IASB. Aan het feit dat geen Nederlander in de nieuwe board werd benoemd kunnen moeilijk conclusies verbonden worden gezien de ondoorzichtigheid van het benoemingsproces, maar het blijft opmerkelijk dat de andere vijf vital nations uit Masons lijst wel allemaal in de eerste board waren vertegenwoordigd en daar elf van de veertien zetels bezetten. Een duidelijker indicator dat Nederland op het tweede plan is geraakt, is dat de RJ niet was opgenomen onder de zogenaamde liaison standard setters waarmee het IASB in het bijzonder hoopte samen te werken. Hoewel de IASB dit idee van liaison standard setters inmiddels heeft laten varen, heeft de IASB op dit moment geen concrete samenwerkingsprojecten met de RJ, in tegenstelling tot bijvoorbeeld de standard setters van de VS, het VK, Canada, Australië, Frankrijk, Duitsland, Noorwegen en Zuid-Afrika. Nederland is niet helemaal buiten beeld, gezien het feit dat er tot 2006 een Nederlander zitting had in zowel de Standards Advisory Council (SAC) als de International Financial Reporting Interpretations Committee (IFRIC). Ook onder de trustees heeft zich altijd een Nederlander bevonden en met ingang van 2008 zelfs als voorzitter van dit belangrijke gezelschap. Ook nemen nog steeds Nederlanders deel aan adviesgroepen voor verschillende vaktechnische projecten van de IASB. Onder de circa 75 personen die sinds 2001 voor kortere of langere tijd deel hebben uitgemaakt van de technische staf van de IASB bevindt zich sinds 2007 ook één Nederlandse practice fellow. Het is dus niet nodig te veronderstellen dat Nederland, en de Nederlanders, er geheel niet meer toe doen, maar dat is toch iets anders dan de onvermijdelijke plaats in de kopgroep waarop Nederland in 1973 kennelijk nog aanspraak kon maken.

Eén manier om hiernaar te kijken is om het te zien als een vanzelfsprekend gevolg van veranderingen in de economische verhoudingen in de wereld. Dat is waar in de zin dat China vermoedelijk nu wel een vital nation is, terwijl het dat in 1973 niet was. Maar daartegenover staat dat de relatieve economische positie van Nederland tussen 1973 en $2001 \mathrm{nu}$ ook weer niet dramatisch is verslechterd. ${ }^{31}$ Belangrijker nog, de aanvankelijk sterke positie van Nederland op het gebied van verslaggeving berustte vermoedelijk veel minder op de economische betekenis van Nederland dan op de kwaliteit van ideeën. Het is al vaker opgemerkt dat Australië niet heel veel groter is dan Nederland, maar op het gebied van verslaggeving de laatste twintig jaar wel veel meer aan de weg timmert.

Het is dus interessant om het kennelijke verlies van de positie als vital nation wat nauwkeuriger in de tijd te lokaliseren en na te gaan of dit statusverlies door beleid in de hand is gewerkt of deels voorkomen had kunnen worden. Het vertrekpunt kunnen we zoeken bij de constatering dat de sterke internationale positie van Nederland in het begin van de jaren zeventig in belangrijke mate berustte op de sterke positie van het NIVRA. Sinds die tijd zijn er twee ontwikkelingen geweest: in de eerste plaats is de positie van de nationale accountantsorganisaties verzwakt in verband met de opkomst, vooral sinds de tweede helft van de jaren tachtig, van de grote internationale accountantsfirma's. In de tweede plaats is het zwaartepunt bij het opstellen van verslaggevingsregels verschoven van het accountantsberoep naar min of meer zelfstandige en geprofessionaliseerde regelgevers. In samenhang daarmee is het accent binnen de regelgeving verschoven van het inventariseren van wat gebruikelijk is naar het ontwikkelen van geheel nieuwe regels die aan de praktijk worden opgelegd. De oprichting van de FASB in 1973 zette, achteraf gezien, duidelijk de toon, maar de FASB kon lange tijd nog als een typisch Amerikaans verschijnsel worden afgedaan. Er is veel voor te zeggen om de oprichting van de Britse Accounting Standards Board in 1990 als de feitelijke doorbraak van deze gedachte te zien.

Het voorgaande betekent dat tot in de tweede helft van de jaren tachtig Nederland, steunend op het NIVRA en de RJ, redelijk in de pas liep en in principe de benodigde infrastructuur had om behoorlijk aan het werk van het IASC bij te dragen. De aanpak van het IASC en de aard van de internationale standaarden verschilden nog niet wezenlijk van wat er in Nederland in de RJ werd gedaan. Men zou zelfs kunnen zeggen dat het falen om gehoor te vinden voor vervangingswaarde een indicatie was dat men te zeer op de 
zaken vooruit liep: leidinggeven aan de praktijk paste op dat moment nog niet goed in de rol die veel regelgevers, inclusief het IASC, in die tijd voor zichzelf zagen.

Ook liep, met uitzondering van Canada, Nederland niet achter bij andere oprichters als het ging om bevordering van bewustzijn en toepassing van internationale standaarden in Nederland. Wel lijkt het zo te zijn dat in het midden van de jaren tachtig het vuur voor het IASC binnen het NIVRA wat lager brandde, maar daar staat tegenover dat in diezelfde tijd ook het IASC zelf wel als enigszins ingedut is getypeerd. Vanaf 1987 is er bij het IASC echter in elk geval geen sprake meer geweest van slaperigheid en ik ben dan ook geneigd om de periode rond 1990 aan te wijzen als het moment waarop Nederland achterop begon te raken. Het gegeven dat Nederland niet in staat of bereid was om deel te nemen aan het werk van de $\mathrm{G}_{4}$, duidt erop dat men niet de slag gemaakt had naar de meer professionele vormen van standard setting die sinds de jaren negentig de ontwikkeling van de externe verslaggeving zo sterk hebben beïnvloed. Zonder op enige wijze de deskundigheid en inzet van Nederlandse betrokkenen gedurende de jaren negentig in twijfel te trekken, lijkt het toch zo te zijn dat de Nederlandse inbreng zich in grote lijnen beperkt heeft tot het reageren op voorstellen van anderen. Belangrijke ontwikkelingen - de balansbenadering, meer fair value, financiële instrumenten en comprehensive income - werden in Nederland eerder passief meegemaakt dan dat er inbreng geleverd kon worden vanuit de eigen nationale regelgeving, hetzij in de vorm van studierapporten, hetzij in de vorm van uitgewerkte standaarden.

Terugkijkend zouden de jaren negentig een goede tijd zijn geweest om een ander type nationale regelgever op te zetten dan de RJ, een regelgever die beter had kunnen functioneren als een forum voor nieuwe ideeën en als kweekvijver voor talent in het inmiddels toch behoorlijk gespecialiseerde ambacht van standard setter. Deze regelgever had nu wellicht kunnen participeren in een van de lopende IASB-projecten.

Hoewel het nu te laat is om, bijvoorbeeld, de RJ alsnog om te vormen tot iets als de Britse Accounting Standards Board - daarvoor is de situatie sinds de Europese IFRS-verordening te zeer veranderd - zou het ook onjuist zijn om te concluderen dat er na deze gemiste kans voor Nederland niets meer te doen valt. Het is in elk geval niet zo dat sinds de oprichting van de IASB alleen nog maar in Londen wordt nagedacht over verslaggeving en dat men in Nederland, afgezien van het sturen van commentaarbrieven, weinig meer kan doen dan de uitkomst afwachten. Het tegendeel is eerder het geval. De IASB heeft te maken met een breed scala aan internationale samenwerkingsverbanden waarin mensen intensiever dan ooit bezig zijn met verslaggeving, zoals de internationale accountantskantoren, sectororganisaties zoals de European Banking Federation, het IMF, het Basels Comité, CESR, het Europees Parlement, maar natuurlijk ook gespecialiseerde instanties als EFRAG en het Accounting Regulatory Committee van de Europese Unie. In al die gremia - om maar te zwijgen van de IASB zelf - worden Nederlandse standpunten verwacht of kunnen ze op zijn minst worden ingebracht.

Het is natuurlijk wel de vraag in hoeverre er zoiets bestaat als een Nederlands standpunt over verslaggeving. Wat dat betreft laat het verleden al zien dat Nederlandse verschaffers, controleurs en gebruikers van verslaggevingsinformatie het niet altijd eens zijn en wellicht gemakkelijker overeenstemming kunnen bereiken met hun tegenhangers elders in Europa dan met elkaar. Het ligt dus voor de hand dat deze groepen, waaraan ook de Nederlandse overheid en de Nederlandse toezichthouders kunnen worden toegevoegd, in elk geval ieder afzonderlijk hun eigen investeringen zullen blijven doen in mensen en kennis om hun standpunten internationaal uit te kunnen dragen.

Toch hebben de genoemde groepen wel een gemeenschappelijk belang en dat is bij deskundigheid om hun standpunt effectief onder woorden te brengen op een manier waar men bij de IASB of elders wat mee kan. Daarvoor is meer nodig dan het kunnen benoemen van het eigen belang bij of de eigen ervaring met een bepaalde verslaggevingsregel. Het gaat ook om gedetailleerde kennis van de bestaande regelgeving om de gevolgen van voorstellen goed te kunnen overzien, om inzicht in de politieke context en de randvoorwaarden waarbinnen de IASB opereert en om inlevingsvermogen in de visies op verslaggeving van zowel de IASB als andere internationale actoren. Mogelijk is het gezamenlijk belang bij dergelijke deskundigheid zo groot dat het loont om een nationaal samenwerkingsverband op te zetten. Dit zou de vorm van een expertisecentrum kunnen hebben, met een kleine vaste staf die de contacten regelt binnen een bredere kring van betrokkenen in het bedrijfsleven en bij de overheid. Het uitwerken van deze gedachte valt buiten het bestek van dit artikel, maar men kan zich voorstellen dat zo'n verband in elk geval taken kan krijgen op het gebied van informatie-uitwisseling, documentatie, advisering, training, het initiëren en ondersteunen van studies en onderzoeksprojecten en het coördineren van internationale stappen wanneer er inderdaad behoefte is om een nationaal standpunt uit te brengen. Dat laatste kan het geval zijn wanneer specifieke Nederlandse omstandigheden onder de aandacht van de IASB gebracht moeten worden, bijvoorbeeld in verband met pensioenen. Bij veel onderwerpen zal echter geen sprake zijn van consensus en zullen de verschillende partijen zelfstandig hun mening kenbaar moeten maken. Het kan echter wenselijk zijn om daarnaast de landelijke organisatie de mogelijkheid te geven om - met inachtneming van nader te bepalen spelregels - onafhankelijk van de 'achterban' een standpunt in te nemen. Dat maakt 
het vermoedelijk gemakkelijker om als partner van de IASB op te treden bij specifieke technische projecten. Een dergelijk platform waar men goed geïnformeerd en onafhankelijk over verslaggeving kan nadenken lijkt mij nuttig voor de vorming of verdere ontwikkeling van talent dat in accountantskantoren, bij de overheid of in het bedrijfsleven kan worden ingezet.

Met de voorgaande opmerkingen beweeg ik mij uiteraard buiten het kader van de historische studie waarop dit artikel is gebaseerd. Ik pretendeer dan ook niet hiermee een volledig onderbouwde visie over het te voeren beleid te geven. Wel ben ik van mening dat de historisch sterke positie van Nederland op dit gebied in belangrijke mate is terug te voeren op bewust beleid en investeringen, met name van het NIV(R)A. Ook al zou er op langere termijn voor Nederland niet meer inzitten dan een positie in het tweede echelon, dan zal ook die positie bewust moeten worden nagestreefd en worden verdiend.

Prof. dr. C. (Kees) Camfferman is als hoogleraar Financial

Accounting verbonden aan de Vrije Universiteit Amsterdam.

\section{Literatuur}

- Bocqueraz, Claude en Peter Walton (2006), Creating a supranational institution: The role of the individual and the mood of the times, Accounting History, vol. 11, no. 3, August, pp. 271-288.

- Camfferman, Kees en Stephen A. Zeff (2007), Financial reporting and global capital markets: A history of the International Accounting Standards Committee, 1973-2000, Oxford: Oxford University Press.

- Camfferman, Kees en Stephen A. Zeff (2008), The formation and early years of the Union Européenne des Experts Comptables Economiques et Financiers (UEC), 1951-1963, or, How the Dutch tried to scupper the UEC, working paper.

- Hopwood, Anthony (1994), Some Reflections on "The harmonization of accounting within the EU", The European Accounting Review, vol. 3, no. 2, pp. 243-253.
- Kirsch, Robert J. (2006), The International Accounting Standards Committee: A political history, z.pl.: Wolters Kluwer UK.

- Hoogendoorn, M.N en G.M.H. Mertens (2000), Kwaliteit van externe financiële verslaggeving in Nederland, brochure symposium 23 november 2000, Universiteit van Amsterdam, Limperg Instituut.

- Mason, Alister K. (1978), The development of International Financial Reporting Standards,

ICRA occasional paper no. 17, Lancaster: International Centre for Research in Accounting, University of Lancaster.

- Schoonderbeek, J.W. en P.E. de Hen (1995), Getuigen van de geschiedenis van het Nederlandse accountantsberoep: 20 interviews, Assen: Van Gorcum.

- Street, Donna L. (2005), Inside G4+1: The Working Group's Role in the evolution of the international accounting standard setting process, London: Institute of Chartered Accountants in England and Wales, Centre for

Business Performance.

- Zeff, Stephen A., Frans van der Wel en Kees Camfferman (1992), Company financial reporting: A historical and comparative study of the Dutch regulatory process, Amsterdam: North-Holland.

- Zeff, Stephen A., Frans van der Wel en Kees Camfferman (2002), A reflection on Company Financial Reporting after 10 Years, Maandblad voor Accountancy en Bedrijfseconomie, jrg. 76, no. 11, november, pp. 513519. 
1 Een uitgebreide behandeling van de geschiedenis van het IASC is te vinden in Camfferman en Zeff (2007) en Kirsch (2006). Voor dit artikel is in belangrijke mate gebruikgemaakt van het materiaal dat werd verzameld ten behoeve van Camfferman en Zeff (2007).

2 Zie voor deze episode Camfferman en Zeff (2008).

3 Van 1967 tot 1972 was dit de zogenaamde International Working Party, van 1972 tot 1977 de International Co-ordinating Committee for the Accountancy Profession (ICCAP).

4 Zie het interview met Tempelaar in Schoonderbeek en De Hen (1995, p. 80).

5 Zie 'Netherlands', notitie van Benson voor vergadering ICAEW Council van 7 december 1966 ICAEW Overseas Relations Committee Minutes, vol. B (1964-1966), pp. 192-195, Guildhall Manuscript Section Ms 35861.

6 'Beleids- en Structuurnota', De Accountant, jrg. 79, no. 3, november 1972, p. 144.

$\mathbf{7}$ De gang van zaken in 1972, en daarmee de rol van Benson, laat zich moeilijk precies reconstrueren. Vergelijk Camfferman en Zeff (2007), p. 43 en voetnoot 3, met Bocqueraz en Walton (2006).

8 De groep van uitgenodigde landen viel, met uitzondering van India en de Filippijnen, samen met het lidmaatschap van ICCAP (zie noot 3). De uitnodigingen aan Japan en Mexico waren niet omstreden, maar in tegenstelling tot de uitnodigingen aan Duitsland, Frankrijk en Nederland werd de noodzaak in de loop van de oprichtingsprocedure hier en daar wel in twijfel getrokken.

9 Bij het tot stand komen van de wettelijke regeling van het accountantsberoep hadden Benson en een aantal van zijn collega's zich aangemeld voor de inschrijving in het accountantsregister teneinde het NIVRA onder druk te zetten om diens stringente regels over samenwerking met buitenlandse accountants te versoepelen. Zie notitie 'Netherlands', december 1966.

10 Zie voor een overzicht van dergelijke bedenkingen: notulen dagelijks bestuur NIVRA 4 april 1973, Nationaal Archief Den Haag, 2.19.089, no. 68 .

11 Hopwood (1994) is de meest bekende verwoording van deze gedachte. Zie Camfferman en
Zeff (2007), p. 537, noot 15 voor andere literatuur op dit punt.

12 Zie Zeff et al. (1992), hoofdstuk 5, voor de geschiedenis van het Tripartiete Overleg.

12 Herman Marseille was in 1985-1986 voorzitter van een kortstondige werkgroep over de harmonisatie van pensioenverslaggeving, Frans Graafstal was van 1987 tot 1989 voorzitter van de stuurgroep die moest adviseren over de status van IAS 15. Henk Treffers leidde van 1974 tot 1981 het zeer moeizame project over vreemde valuta (IAS 21). Hij werd in 1981 afgelost door de Japanner Nakajima, onder wiens leiding het project in 1983 werd afgerond.

14 Hierbij moet aangetekend worden dat de stemverhoudingen bij enkele stemmingen rond 1980 niet meer te reconstrueren zijn en dat van sommige stemmingen uit dezelfde periode alleen nog de stemverhoudingen bekend zijn, maar niet de identiteit van de tegenstemmende delegaties. Deze onzekerheid staat de conclusie niet in de weg dat de Nederlandse delegatie bij de eindstemmingen vrijwel altijd vóór stemde.

15 De oorspronkelijke G4 bestond uit de regelgevers van Australië, Canada, het Verenigd Koninkrijk en de Verenigde Staten. Nieuw-Zeeland werd hier later aan toegevoegd. De ' +1 ' duidde op het feit dat het IASC een waarnemer naar de vergaderingen stuurde. Zie Street (2005) voor een behandeling van de geschiedenis van de G4+1.

16 Zie hiervoor Zeff et al. (2002), p. 515.

17 Dat wil zeggen, Duitsland, Frankrijk, Nederland, het Verenigd Koninkrijk en de Noordse Accountantsfederatie (in feite een gezamenlijke vertegenwoordiging van Denemarken, Noorwegen en Zweden). De '+2' stond voor de Europese Commissie en de Fédération des Experts Comptables Européens (FEE).

18 Met ingang van 1982 was deze verplichting formeel verbonden aan het lidmaatschap van IFAC, omdat het lidmaatschap van het IASC sindsdien gekoppeld was aan het lidmaatschap van IFAC. 19 'NIVRA-verplichtingen nopens Internationale Standaarden van het IASC', De Accountant, jrg. 82, no. 10, juni 1976, pp. 616-617.

20. 'Internationale standaarden voor de jaarrekening', De Accountant, jrg. 85, no. 2, oktober 1978, p. 84
21 Zie voor deze episode Zeff et al. (1992), pp. 310-316.

22 Zeff et al. (1992), p. 251.

23 'Een nieuwe verspreidingswijze voor internationale discussie-ontwerpen en uitspraken', De Accountant, jrg. 90, no. 10 (juni 1984), p. 742. De aangehaalde opmerking en de genoemde beleidswijziging golden ook voor de uitspraken van IFAC en de UEC.

24! 'Commentaar op ED 32 "Comparability of Financial Statements"', De Accountant, jrg. 96, no. 2 (oktober 1989), pp. 71-73.

25 Zie de ontwikkeling van de paragraaf 'Relatie tussen Standaarden van het IASC en de (ontwerp)Richtlijnen' in het 'Verslag van de werkzaamheden' van de Raad voor de Jaarverslaggeving over de jaren 1987-1991.

26 Raad voor de Jaarverslaggeving 'Verslag van werkzaamheden over 1997', paragraaf 2.8 .

27 Raad voor de Jaarverslaggeving 'Verslag van werkzaamheden over 1999', paragraaf 2.8 .

28 Voor een vergelijkbare aanbeveling, zie 'Prof. Traas wil aanscherping boekhoudregels', Het Financieele Dagblad, 25 november 1998, supplement, p. 7 .

29. Gezamenlijke commentaarbrief van NIVRA, RJ, VNO-NCW, FNV, CNV en VBA aan Sir Bryan Carsberg, 22 april 1999 (archief IASC). Deze brief had betrekking op de discussion paper Shaping IASC for the Future van december 1998. In deze discussion paper werd niet de uiteindelijke opzet van de IASB voorgesteld, maar een structuur waarin standaarden zouden worden ontworpen in een Standards Development Committee, bestaande uit vertegenwoordigers van nationale regelgevers. De standaarden zouden worden goedgekeurd door een vergrote board, benoemd door trustees. De trustees op hun beurt zouden benoemd worden door een reeks internationale organisaties waaronder IFAC.

30 Interview met Jan Klaassen, 28 mei 2005. 21 Volgens de gegevens van Angus Maddison daalde het aandeel van Nederland in het wereldwijde GDP van 1,1 procent in 1973 tot 0,92 procent in 2001. Zie de tabellen op www.ggdc.net. 